\title{
African horse sickness in naturally infected, immunised horses
}

\author{
C. T. WEYER, M. QUAN ${ }^{\dagger}$, C. JOONE, C. W. LOURENS, N. J. MacLACHLAN and A. J. GUTHRIE* \\ Equine Research Centre, Faculty of Veterinary Science, University of Pretoria, Onderstepoort, South Africa \\ †Department of Veterinary Tropical Diseases, Faculty of Veterinary Science, University of Pretoria, Onderstepoort, South Africa \\ ‡Department of Pathology, Microbiology and Immunology, School of Veterinary Medicine, University of California, USA.
}

*Correspondence email: alan.guthrie@up.ac.za; Received: 25.10.11; Accepted: 13.04 .12

\section{Summary}

To determine whether subclinical cases, together with clinical cases, of African horse sickness (AHS) occur in immunised horses in field conditions, whole blood samples were collected and rectal temperatures recorded weekly from 50 Nooitgedacht ponies resident in open camps at the Faculty of Veterinary Science, University of Pretoria, Onderstepoort, during 2008-2010. The samples were tested for the presence of African horse sickness virus (AHSV) RNA by a recently developed real-time RT-PCR. It was shown that $16 \%$ of immunised horses in an AHS endemic area were infected with AHSV over a 2 year period, with half of these (8\%) being subclinically infected. The potential impact of such cases on the epidemiology of AHS warrants further investigation.

Keywords: horse; African horse sickness virus; real-time RT-PCR; subclinical infection; prospective study; vaccination

\section{Introduction}

African horse sickness (AHS) is the most devastating of all equine diseases, with a mortality rate of up to $90 \%$ in naïve horses [1]. Due to the nature of AHS, strict quarantine measures are applied to equids exported from AHS-endemic areas, and the disease has a profound and negative economic impact on the equine industries of countries where the disease is endemic.

The possibility that a horse could be infected subclinically with African horse sickness virus (AHSV) was raised following an outbreak of AHS, in 2006 , in the south west of South Africa, an area normally free of the disease [2]. The outbreak was thought to have originated from a fully vaccinated horse that showed no clinical signs of AHS and had moved into the area from an AHS-endemic area.

Detection of horses infected subclinically with AHSV is possible by means of a real-time RT-PCR assay, which is capable of detecting AHSV viraemia prior to the development of clinical signs. The assay was developed using sequences from field strains of AHSV and has been used in experimental AHS infection studies [3]

Although horses resident at the Faculty of Veterinary Science, University of Pretoria, Onderstepoort, are vaccinated every year with a commercial live-attenuated polyvalent AHSV vaccine, clinical cases of AHS still occur regularly within this herd, and the prevalence of AHS in the area is high. The aim of our study was to follow a herd of immunised horses in an AHSV-endemic area longitudinally during the AHS season and to establish whether subclinical cases of AHS occurred naturally in field conditions.

\section{Materials and methods}

Fifty horses with known AHS vaccination histories were included in this study. All horses, with the exception of newborn foals, had been vaccinated at least once with the AHS polyvalent vaccines ${ }^{a}$, according to the manufacturer's recommendations. Rectal temperatures were recorded with a digital thermometer and blood samples collected by jugular venepuncture in EDTA tubes from each horse on a weekly basis during the 2008-2009 and 2009-2010 AHS seasons (December-May). All horses tested negative for AHSV by RT-PCR at the start of both seasons. The vaccination status of the herd ranged from horses that had been vaccinated up to 24 times in their life to foals that were not vaccinated prior to or during the study (Table 1).

The whole blood samples were tested on the day of collection for the presence of AHSV RNA with a modification of an RT-PCR assay [3]. Briefly, nucleic acid was extracted from $100 \mu$ of whole blood using the MagMAX ${ }^{\mathrm{TM}}$ Viral RNA Isolation kit $^{\mathrm{b}}$ and a KingFisher 96 Magnetic Particle Processor $^{c}$, according to the manufacturer's protocol. Five microlitres of eluate were denatured together with primers and probes targeting the AHSV S8 (VP7) gene in a final volume of $10 \mu \mathrm{l}$ for $1 \mathrm{~min}$ at $95^{\circ} \mathrm{C}$.
VetMax ${ }^{\mathrm{TM}}$-Plus Multiplex One-Step RT-PCR kit ${ }^{\mathrm{b}}$ reagents were added, and a one-step RT-PCR was performed on a StepOnePlus ${ }^{\text {Tm }}$ Real-Time PCR System ${ }^{b}$, using a final primer and probe concentration of 400 and $180 \mathrm{nM}$, respectively, and a protocol recommended by the manufacturer. Samples were classified as positive if the normalised fluorescence exceeded a 0.1 threshold within 40 PCR cycles. Cycle threshold $\left(C_{T}\right)$ was defined as the cycle number during which the fluorescence threshold was reached.

Additional whole blood samples were collected daily from horses that tested positive by AHSV RT-PCR. A complete blood count was performed, and the temperature and clinical signs/symptoms were recorded. The duration of sampling from AHSV-positive animals was as follows: blood samples were collected and data recorded daily for 5 consecutive days. Thereafter, sampling was reduced to twice weekly until 3 consecutive samples were negative for AHSV by RT-PCR or 30 days after the original positive sample was taken (for nonpyrexic horses, with temperatures not exceeding $39^{\circ} \mathrm{C}$ ), or 120 days after the original positive sample was collected (for pyrexic horses with temperatures exceeding $39^{\circ} \mathrm{C}$ ). Viral isolation on BHK-21 tissue culture was attempted from the whole blood samples, as previously described [4].

This study was approved by the University of Pretoria's Animal Use and Care Committee according to the South African National Standard (SANS 10386: 2008) for the care and use of animals for scientific purposes.

\section{Results}

The incidence of AHS cases confirmed by RT-PCR was $12 \%$ ( 6 of 50 horses) during the 2009 summer and $4 \%$ ( 2 of 50 horses) during the 2010 summer. The mean annual incidence of AHS in the study population was $8 \%$. Of the 8 AHS cases, 2 suffered from the cardiac form, 2 from the horse sickness fever form, and 4 horses were infected subclinically. Two horses that presented with the moderate cardiac ('dikkop') form of AHS were both AHSV positive by RT-PCR for $>130$ days and severely thrombocytopenic during the early stages of the disease (Fig 1). The RT-PCR results and thrombocyte counts of 2 mild clinical cases of AHS are presented in Figure $2 a$ and $b$. The clinical signs manifested by these 2 horses were $a$ slight fever and mild supraorbital swelling. Both animals were AHSV positive by RT-PCR for more than 30 days. Both cases had a marked thrombocytopenia that resolved within a week. Four subclinical cases of AHS were detected by RT-PCR, and findings from 2 representative cases are shown in Figure $2 \mathrm{c}$ and $\mathrm{d}$. These horses showed no altered clinical appearance, being neither pyrexic nor thrombocytopenic, nor did they show any other haematological abnormality. All cases were AHSV negative by RT-PCR by day 30. No consistent changes were noted in any of the other haematological data obtained from any of these horses (Supplementary Item Table 51).

Infection with AHSV occurred in horses that had been vaccinated annually up to 5 times (Table 1), but was not detected in horses vaccinated 
TABLE 1: Herd vaccination history, showing the number of vaccinations, the number of horses in each vaccination category, the clinical and subclinical African horse sickness (AHS) cases within each category and the total number and percentage of AHS RT-PCR-positive cases within each category

\begin{tabular}{|c|c|c|c|c|c|}
\hline $\begin{array}{l}\text { Number of times } \\
\text { vaccinated }\end{array}$ & $\begin{array}{l}\text { Number of horses } \\
\text { vaccinated }\end{array}$ & $\begin{array}{l}\text { Clinical AHS cases } \\
\text { within category }\end{array}$ & $\begin{array}{l}\text { Subclinical AHS cases } \\
\text { within category }\end{array}$ & $\begin{array}{l}\text { Total AHS RT-PCR-positive } \\
\text { cases within category }\end{array}$ & $\begin{array}{l}\text { Percentage AHS } \\
\text { RT-PCR-positive } \\
\text { cases within category }\end{array}$ \\
\hline 0 & 11 & - & 1 & 1 & 9 \\
\hline 1 & 2 & 1 & - & 1 & 50 \\
\hline 2 & 4 & - & 1 & 1 & 25 \\
\hline 3 & 8 & 1 & 1 & 2 & 25 \\
\hline 4 & 3 & 2 & - & 2 & 66 \\
\hline 5 & 3 & - & 1 & 1 & 35 \\
\hline$>6$ & 19 & - & - & 0 & 0 \\
\hline Total & 50 & 4 & 4 & 8 & - \\
\hline
\end{tabular}

$\geq 6$ times. However, horses that had been vaccinated $\geq 6$ times were also older, thus potentially having been exposed repeatedly to AHSV in the field.

\section{Discussion}

The incidence of RT-PCR-positive AHS cases in the 50 horses included in this study was $16 \%$ over the 2 year period. Two of these cases (4\%) presented as clinical AHS and 6 (12\%) were mild clinical or subclinical cases. The data suggest that horses that have been immunised against AHSV can be both clinically and subclinically infected with AHSV following natural infection in field conditions.

In this study, AHSV RNA was detected for more than 130 days in blood samples from clinical cases. From mild or subclinical cases of AHS, AHSV RNA was detected in blood samples for up to 40 days. It is likely that the RT-PCR assay detected erythrocyte-associated AHSV RNA, which was not necessarily infectious. Bluetongue virus, an orbivirus closely related to AHSV, has been shown to be erythrocyte bound [5], and the lifespan of an erythrocyte in the circulation can be in excess of 145 days [6], which may also explain the extended detection of AHSV nucleic acid in the blood of infected horses by RT-PCR. The period during which horses can be infectious to midges is not known but, given the potential importance to virus transmission in the field, this aspect of the pathogenesis of AHSV infection of horses warrants further investigation.

Infectious AHSV can be isolated from the blood of experimentally infected naïve horses for up to 21 days [7]. African horse sickness virus was not isolated in cell culture from any of the naturally infected RT-PCR-positive equine blood samples collected in this study. As these horses were either vaccinated or young foals with maternally derived antibody, it is possible that AHSV was bound by neutralising antibodies that interfered with infection of the cell cultures used for virus isolation. Failure to isolate AHSV precluded further evaluation of the infecting serotype. The RT-PCR is therefore more sensitive in the detection of AHSV than conventional virological methods in previously immunised, naturally infected horses in field conditions.

This study showed that horses that have been immunised against AHSV can be infected both clinically and subclinically with AHSV following natural infection in field conditions. The level of viraemia seen in the subclinically infected horses might be sufficient to infect midges with AHSV, although this aspect of subclinical equine AHSV infection clearly requires further investigation, given its potential significance to the dissemination of AHSV.

\section{Conflicts of interest}

No conflicts of interest have been declared.

\section{Source of funding}

Equine Research Centre, Faculty of Veterinary Science, University of Pretoria, Private Bag X04, Onderstepoort, 0110, South Africa.

\section{Acknowledgements}

Our thanks to the Department of Veterinary Tropical Diseases and the Veterinary Genetics Laboratory, University of Pretoria, for the use of laboratory equipment and facilities, and to the Onderstepoort Teaching Animal Unit for the use of their horses in this study and for providing staff members who assisted with sample collection.
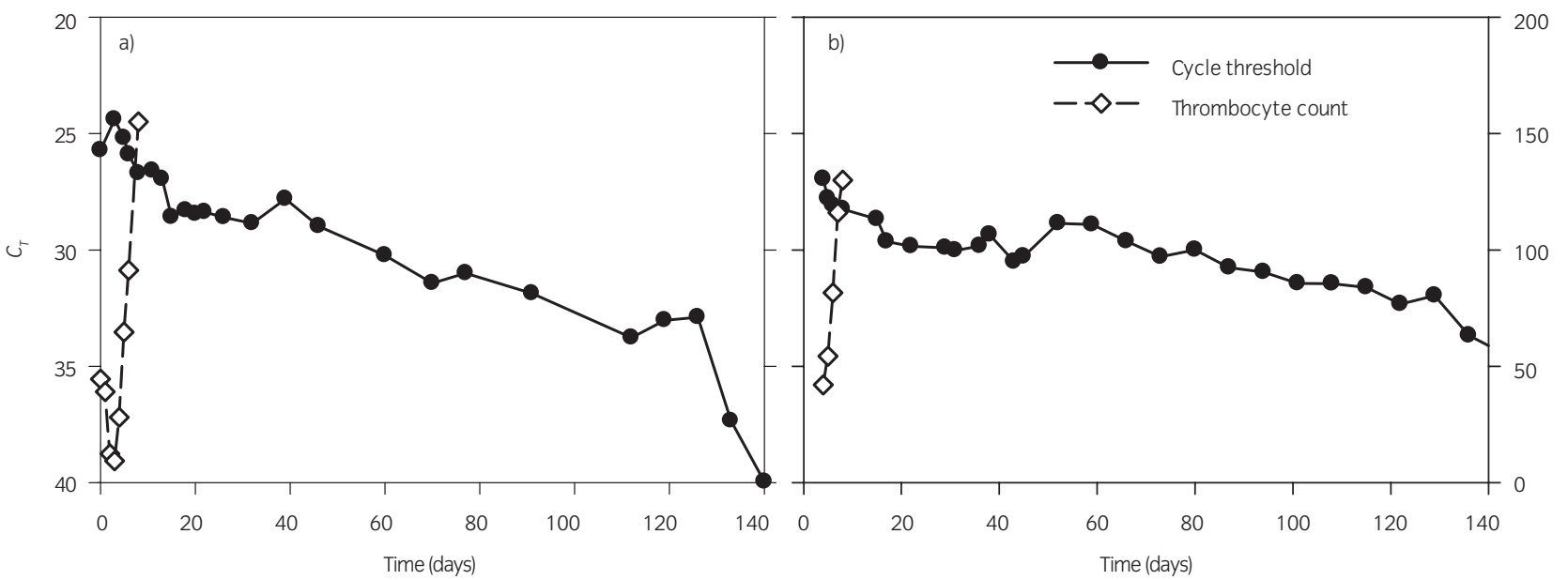

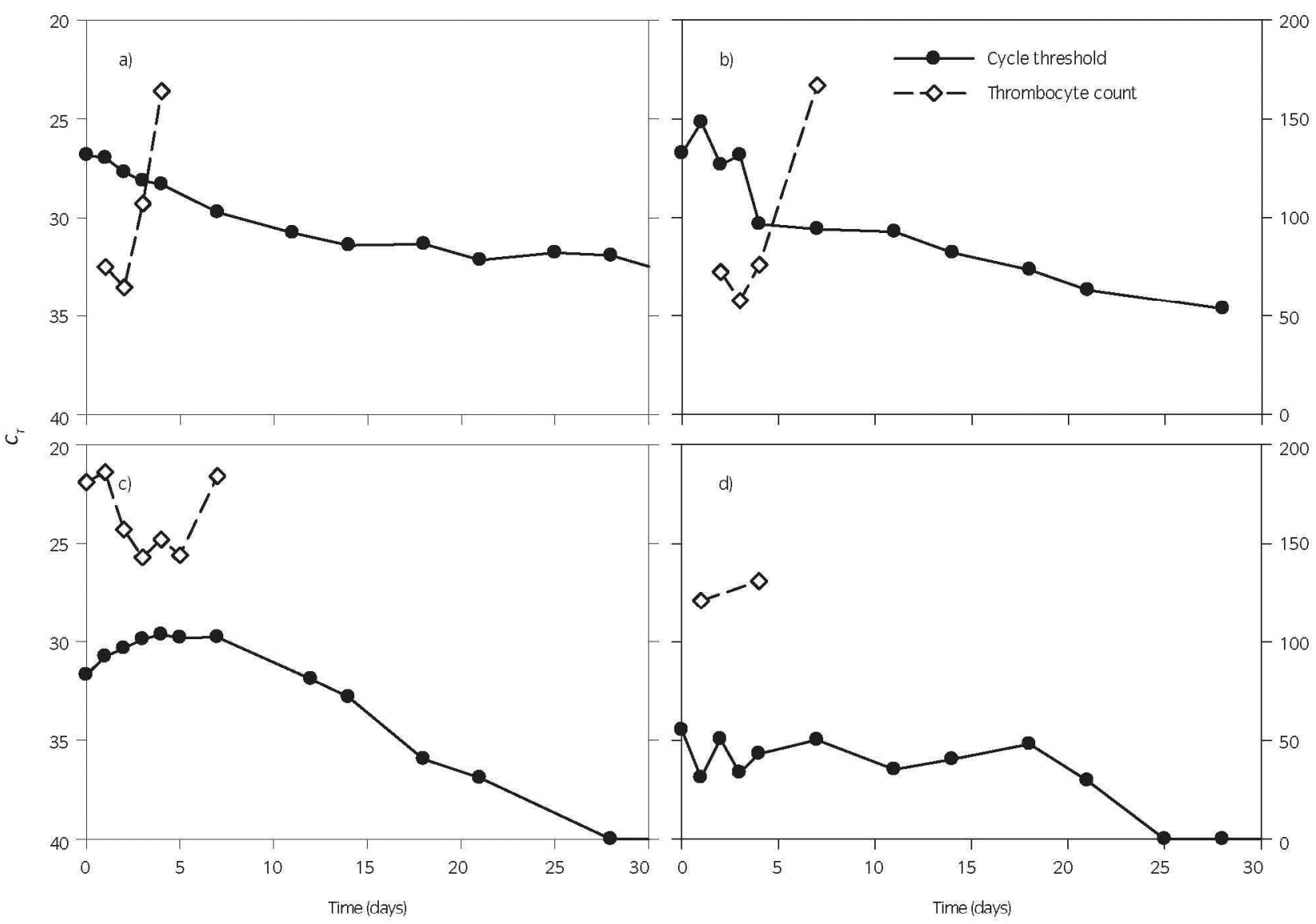

Fig 2: Temporal changes in viral load $\left(C_{T}\right)$ and thrombocyte count $\left(\times 10^{9} /\right)$ in blood samples from ponies infected naturally with African horse sickness virus. Cases $3(a)$ and 4 (b) presented as mild clinical cases (horse sickness fever form). Cases 5 (c) and 6 (d) were subclinical cases of African horse sickness.

\section{Manufacturers' addresses}

Onderstepoort Biological Products, Pretoria, Gauteng, South Africa.

'Life Technologies" ${ }^{1 \prime}$, Carlsbad, California, USA.

'Thermo Fisher Scientific Inc., Waltham, Massacheusetts, USA.

\section{References}

1. Guthrie, AJ. and Quan, M. (2009) African horse sickness. In: Infectious Diseases of the Horse, 4th edn., Eds: T.S. Mair and R.E. Hutchinson, Equine Veterinary Journal Ltd, Cambridgeshire. pp 72-82.

2. ProMED-mail (2006) African horse sickness - South Africa (Western Cape)(02): OIE ProMED-mail, 09 May, 20060509.1335. online at: http://www. promedmail org (accessed on 20 May 2009).

3. Quan, M., Lourens, C.W., MacLachlan, N.J., Gardner, I.A. and Guthrie, A.J. (2010) Development and optimisation of a duplex real-time reverse transcription quantitative PCR assay targeting the VP7 and NS2 genes of African horse sickness virus. J. Virol. Methods 167, 45-52.

4. Quan, M., van Vuuren, M., Howell, P.G., Groenewald, D. and Guthrie, A.J. (2008) Molecular epidemiology of the African horse sickness virus $\$ 10$ gene. J. Gen. Virol. 89, 1159-1168.
5. Hassan, S.S. and Roy, P. (1999) Expression and functional characterization of bluetonge virus VP2 protein: role in cell entry. J. Virol. 73, 9832-9842.

6. Latimer, K.S., Mahaffey, E.A. and Prasse, K.W. (2003) Duncan and Prasse's Veterinary Laboratory Medicine: Clinical Pathology, 4th edn., lowa State Press, Ames, lowa.

7. Coetzer, J.A.W. and Guthrie, A.J. (2004) African horse sickness. In: Infectious Diseases of Livestock, Eds: J.A.W. Coetzer and R.C. Tustin, Oxford University Press, Cape Town. pp 1231-1246. 


\section{Supporting Information}

Table S1: Results of selected clinical, virological and haematological data from horses naturally infected with AHSV: cycle threshold $\left(\mathrm{C}_{\mathrm{T}}\right)$ values, Haematocrit $(\mathrm{Ht})$, Haemoglobin concentration $(\mathrm{Hgb})$, Red cell count (RCC), Neutrophil count (Neut), Lymphocyte count (Lymph) and rectal temperature of each horse. (Normal values: $\mathrm{C}_{\mathrm{T}}$ value: negative $=40 ; \mathrm{Ht}=0.24-0.44 \mathrm{~L} / \mathrm{L} ; \mathrm{Hgb}=80-140 \mathrm{~g} / \mathrm{L} ; \mathrm{RCC}=$ $5.5-9.5 \times 10^{12} / \mathrm{L} ;$ Neut $\left.=3.54-7.08 \times 10^{9} / \mathrm{L} ; \mathrm{Lymph}=1.8-3.6 \times 10^{9} / \mathrm{L} ; \mathrm{Temp}=<39^{\circ} \mathrm{C}\right)$. 


\begin{tabular}{|c|c|c|c|c|c|c|c|c|}
\hline Case No. & Days & $\mathrm{C}_{\mathrm{T}}$ & $\mathrm{Ht}(\mathrm{L} / \mathrm{L})$ & $\mathrm{Hgb}(\mathrm{g} / \mathrm{L})$ & $\operatorname{RCC}\left(\times 10^{12} / L\right)$ & $\operatorname{Neut}\left(\times 10^{9} / \mathrm{L}\right)$ & $\operatorname{Lymph}\left(\times 10^{9} / \mathrm{L}\right)$ & $\operatorname{Temp}\left({ }^{\circ} \mathrm{C}\right)$ \\
\hline \multirow[t]{9}{*}{ Case 1} & 0 & 25.72 & 0.30 & 109 & 6.65 & 3.49 & 1.27 & 40.0 \\
\hline & 1 & & 0.29 & 108 & 6.58 & 2.46 & 3.20 & 38.3 \\
\hline & 2 & & 0.30 & 113 & 6.81 & 1.81 & 2.66 & 37.0 \\
\hline & 3 & 24.40 & 0.33 & 120 & 7.36 & 1.87 & 3.37 & 37.2 \\
\hline & 4 & & 0.28 & 108 & 6.37 & 3.36 & 2.85 & 37.0 \\
\hline & 5 & 25.20 & 0.28 & 102 & 6.19 & & 3.68 & 37.2 \\
\hline & 6 & 25.91 & 0.26 & 89 & 5.51 & 5.20 & 3.73 & 37.5 \\
\hline & 7 & & & & & & & 37.4 \\
\hline & 8 & 26.71 & 0.22 & 82 & 4.98 & 7.44 & 4.77 & 37.5 \\
\hline \multirow[t]{5}{*}{ Case 2} & 0 & 26.96 & 0.23 & 76 & 5.33 & 4.91 & 4.21 & 37.8 \\
\hline & 1 & 27.80 & 0.19 & 65 & 4.63 & 5.80 & 3.54 & 37.9 \\
\hline & 2 & 28.09 & 0.19 & 70 & 4.61 & 5.52 & 5.75 & 37.3 \\
\hline & 3 & 28.38 & 0.19 & 63 & 4.38 & 5.71 & 4.92 & 36.4 \\
\hline & 4 & 28.25 & 0.21 & 72 & 4.95 & 6.44 & 5.81 & 37.9 \\
\hline \multirow[t]{5}{*}{ Case 3} & 0 & 26.85 & & & & & & 38.6 \\
\hline & 1 & 26.99 & 0.26 & 98 & 5.95 & 3.66 & 3.66 & 37.5 \\
\hline & 2 & 27.71 & 0.25 & 94 & 5.77 & 4.16 & 3.64 & 37.0 \\
\hline & 3 & 28.15 & 0.27 & 99 & 6.08 & 3.48 & 4.81 & 37.2 \\
\hline & 4 & 28.33 & 0.24 & 92 & 5.52 & 5.49 & 4.22 & 37.5 \\
\hline \multirow[t]{6}{*}{ Case 4} & 0 & 26.74 & & & & & & 38.1 \\
\hline & 1 & 25.17 & & & & 5.02 & 3.13 & 38.7 \\
\hline & 2 & 27.33 & 0.28 & 133 & 6.29 & 4.07 & 2.84 & 38.1 \\
\hline & 3 & 26.84 & 0.28 & 103 & 6.31 & 3.28 & 3.31 & 36.8 \\
\hline & 4 & 30.34 & 0.26 & 100 & 6.04 & 4.11 & 4.10 & 37.9 \\
\hline & 7 & 30.59 & 0.29 & 108 & 6.60 & 6.16 & 4.74 & 36.5 \\
\hline \multirow[t]{7}{*}{ Case 5} & 0 & 31.69 & 0.37 & 126 & 7.73 & 1.65 & 2.86 & 37.2 \\
\hline & 1 & 30.77 & 0.34 & 117 & 7.08 & 2.86 & 2.73 & 38.3 \\
\hline & 2 & 30.35 & 0.32 & 115 & 7.11 & 3.35 & 2.47 & 38.9 \\
\hline & 3 & 29.89 & 0.29 & 105 & 6.04 & 2.47 & 2.14 & 38.1 \\
\hline & 4 & 29.66 & 0.36 & 121 & 7.54 & 2.10 & 3.33 & 37.8 \\
\hline & 5 & 29.81 & 0.32 & 105 & 6.62 & 2.46 & 2.37 & 37.3 \\
\hline & 7 & 29.79 & 0.35 & 117 & 7.36 & 2.82 & 2.96 & 36.9 \\
\hline \multirow[t]{5}{*}{ Case 6} & 0 & 34.48 & & & & & & 37.9 \\
\hline & 1 & 36.90 & 0.29 & 105 & 6.71 & 3.26 & 9.14 & 37.0 \\
\hline & 2 & 34.94 & & & & & & 37.5 \\
\hline & 3 & 36.65 & & & & & & 37.5 \\
\hline & 4 & 35.69 & 0.27 & 97 & 6.23 & 3.63 & 8.81 & 37.3 \\
\hline \multirow[t]{5}{*}{ Case 7} & 0 & 35.70 & & & & & & 37.6 \\
\hline & 1 & 35.96 & 0.33 & 122 & 8.19 & 3.54 & 6.97 & 37.2 \\
\hline & 2 & & 0.31 & 110 & 7.57 & 3.49 & 4.54 & 37.6 \\
\hline & 3 & & 0.29 & 106 & 7.21 & 4.53 & 4.50 & 37.3 \\
\hline & 4 & & 0.30 & 110 & 7.51 & 4.50 & 4.31 & 37.0 \\
\hline \multirow[t]{5}{*}{ Case 8} & 0 & 30.18 & & & & & & 38.1 \\
\hline & 1 & & 0.30 & 113 & 9.39 & 4.80 & 8.05 & 37.8 \\
\hline & 2 & 32.67 & & & & & & 38.2 \\
\hline & 3 & 33.71 & & & & & & 37.5 \\
\hline & 4 & & 0.35 & 125 & 10.47 & 4.13 & 7.29 & 37.3 \\
\hline
\end{tabular}

